\title{
Troussey
}

Carrière de sables et de graviers alluvionnaires GSM

\section{Philippe Lefèvbre}

\section{(2) OpenEdition \\ 12 Journals}

Édition électronique

URL : http://journals.openedition.org/adlfi/8832

ISSN : 2114-0502

Éditeur

Ministère de la culture

Référence électronique

Philippe Lefèvbre, «Troussey », ADLFI. Archéologie de la France - Informations [En ligne], Lorraine, mis en ligne le 01 mars 2001, consulté le 03 mai 2019. URL : http://journals.openedition.org/adlfi/8832

Ce document a été généré automatiquement le 3 mai 2019.

(c) Ministère de la Culture et de la Communication, CNRS 


\section{Troussey}

Carrière de sables et de graviers alluvionnaires GSM

\section{Philippe Lefèvbre}

Identifiant de l'opération archéologique : F1355200100036

Date de l'opération : 2001 (EV)

1 Conformément à l'arrêté préfectoral d'autorisation d'extraction de sables alluvionnaires, une campagne de sondages archéologiques a été réalisée préalablement à la première tranche d'exploitation de 2 ha. Bien que situés dans un secteur reconnu à forte potentialité, les sondages n'ont révélé aucun vestige significatif.

INDEX

Index géographique : Lorraine, Meuse (55), Troussey

operation Fouille d'évaluation (EV)

\section{AUTEURS}

PHILIPPE LEFÈVBRE

AFAN 